nephron

Practice

\title{
You Only Can Treat and Prevent What You Know
}

\author{
Ivo Laranjinha ${ }^{a}$ Esteban Porrini ${ }^{b}$ \\ ${ }^{a}$ Hospital de Santa Cruz, Centro Hospitalar de Lisboa Ocidental, Lisbon, Portugal; ${ }^{b}$ Faculty of Medicine, Instituto de \\ Tecnologías Biomédicas, Universidad de La Laguna, Santa Cruz de Tenerife, Spain
}

A few years ago, we started finding, for the first time, expressions such as "histologic reversibility," or "change in the natural history" referring to diabetic nephropathy (DN) - a hopeful surprise. Reports showed the reversibility of renal histopathologic changes in native kidneys after pancreatic transplantation and in renal grafts from diabetic donors after kidney transplantation $[1,2]$. Also, the normalization of the classic clinical signs of DN like microalbuminuria has been described [3]. Taken together these data suggest that the earlier clinicopathologic findings of $\mathrm{DN}$ are dynamic, rather than irreparable, opening the door for the reversibility of the early stages of DN.

This optimism was revitalized after the publication of a series of studies showing a potential delay in $\mathrm{DN}$ progression with new antidiabetic drugs, an effect that proved to be independent of the hypoglycemic effect $[4,5]$.

There is an optimistic mood in this field, as many believe that we are in a new era, in which for the first time we can act specifically in one of the early pathogenic paths of DN like glomerular hyperfiltration and increased tubular sodium reabsorption.

Following the above, a better understanding of the pathogenesis, the natural history of DN (namely, the earliest stages), and the earliest clinical manifestations of the disease are of utmost importance - specifically when reversing the lesions and modifying the natural history of $\mathrm{DN}$ seem to be a reality [6].

\section{KARGER}

() 2019 S. Karger AG, Basel

E-Mail karger@karger.com

www.karger.com/nef
In opposition to the beginning of the century, we now know that $\mathrm{DN}$ is not only a glomerular disease but also a tubular, interstitial, and vascular disease [7, 8]. With this in mind, the classic (but weak) clinical markers of glomerular lesions should be reinforced with new reliable markers able to mark the earliest histologic changes - not only glomerular [6-9].

Apart from the diabetes, amidst the changes in the metabolic syndrome, we should give more attention to renal lipotoxicity (analogous to the nonalcoholic fatty liver disease) and to childhood obesity and its impacts on the kidney.

The ENBiBA project of the DIABESITY Working Group of the European Renal Association/European Dialysis and Transplantation Association was created to investigate the natural history of DN (namely, the different phenotypes of this disease) and specifically the early stages (not biopsied in the clinical everyday life) [10].

These issues constituted the main points discussed in the CME course sponsored by the DIABESITY Working Group of the European Renal Association/European Dialysis and Transplantation Association, which was held in Lisbon, Portugal, on November 24 and 25, 2017.

Contribution from the CME Course of the DIABESITY Working Group of the European Renal Association/European Dialysis and Transplantation Association, Lisbon, November 24-25, 2017.

Ivo Laranjinha, MD 


\section{References}

1 Harada S, Ushigome H, Nishimura A, Nakao T, Nakamura T, Koshino K, et al. Histological reversibility of diabetic nephropathy after kidney transplantation from diabetic donor to non-diabetic recipient. Nephrology (Carlton). 2015 Jul;20(suppl 2):40-4.

2 Fioretto P, Barzon I, Mauer M. Is diabetic nephropathy reversible? Diabetes Res Clin Pract. 2014 Jun;104(3):323-8.

3 Perkins BA, Ficociello LH, Silva KH, Finkelstein DM, Warram JH, Krolewski AS. Regression of microalbuminuria in type 1 diabetes. N Engl J Med. 2003 Jun;348(23):2285-93.

4 Prischl FC, Wanner C. Renal Outcomes of Antidiabetic Treatment Options for Type 2 Diabetes-A Proposed MARE Definition. Kidney Int Rep. 2018 Apr;3(5):1030-8.
5 Sarafidis P, Ferro CJ, Morales E, Ortiz A, Malyszko J, Hojs R, et al. SGLT-2 inhibitors and GLP-1 receptor agonists for nephroprotection and cardioprotection in patients with diabetes mellitus and chronic kidney disease. A consensus statement by the EURECA-m and the DIABESITY working groups of the ERA-EDTA. Nephrol Dial Transplant. 2019 Feb;34(2):208-30.

6 Brodkin E, Copes R, Mattman A, Kennedy J, Kling R, Yassi A. Lead and mercury exposures: interpretation and action. CMAJ. 2007; 176(1):59-63.

7 Porrini E, Ruggenenti P, Mogensen CE, Barlovic DP, Praga M, Cruzado JM, et al.; ERAEDTA diabesity working group. Non-proteinuric pathways in loss of renal function in patients with type 2 diabetes. Lancet Diabetes Endocrinol. 2015 May;3(5):382-91.

8 Laranjinha I, Matias P, Mateus S, Aguiar F, Pereira P, Perneta Santos M, et al. Diabetic kidney disease: is there a non-albuminuric phenotype in type 2 diabetic patients? Nefrologia. 2016 Sep - Oct;36(5): 503-9.

9 Kamijo-Ikemori A, Sugaya T, Kimura K Novel urinary biomarkers in early diabetic kidney disease. Curr Diab Rep. 2014 Aug; 14(8):513.

10 EraEdta Scientific Working Groups - PROJECTS [Internet]. [cited August 7, 2019]. Available from: http://www.era-edtaworkinggroups.org/en-US/group/diabesity/ projects\#sthash.dVtYRNCh.dpbs. 